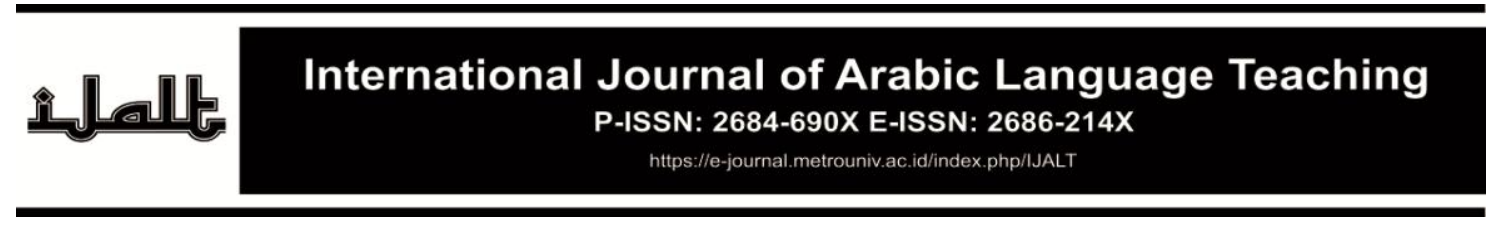

\title{
The Urgency of Enhancing Learning Arabic Inside National Education Curriculum in Indonesia
}

\author{
Ahmad Bukhari Muslim¹, Rodhy Harisca ${ }^{2}$ \\ ${ }_{1}^{1}$ UIN Raden Intan Lampung, Indonesia \\ 2IAIN Metro, Indonesia
}

Article History:

Received : February 16,2021

Revised : May 17, 2021

Accepted : June 6, 2021

Published : June 6, 2021

Keywords:

Strategic Position;

Strengthened; Teaching Arabic.

*Correspondence Address:

bukharimuslim@radenintan.ac.id
Abstract: The objectives of this article is to identify the urgency of enhancing learning arabic inside national education curriculum in Indonesia. The urgency of this research is to conduct the development of teaching Arabic. The article adopted the qualitative descriptive method as the research designed the urgency of enhancing learning arabic inside national education curriculum. Data were analyzed by applying the four steps of Creswell's version collecting data, grouping, selecting, then interpreting the data and the data source was a documents review. The article findings indicated that learning arabic has a strategic position inside national education curriculum, as discussing about the urgency of enhancing learning arabic inside national education curriculum. Based on the research findings, the authors recommended the existence of Arabic inside national education curriculum should be strengthened and developed.

\section{INTRODUCTION}

The field of Arabic education for non-Arabic speakers is premature, requiring a lot of study and research covering all aspects of Arabic as a second language or foreign language education process. The aspects that need to be studied include curriculum, teaching materials, preparation of teaching staff, education based on modern technology, and various ways of studying language through traditional methods (Qawa'id wa Tarjamah) as well as alternative methods and other problems related to teaching staff and educational environment.

This is important to study because Arabic language education is not only limited to the delivery of knowledge to students but also involves language habituation and practice on an ongoing basis. As in some Islamic boarding schools, students are accustomed to communicating using Arabic in their daily 
interactions. Therefore, students will be able to build good and effective communication when interacting with native speakers.

The study of Arabic as a foreign language education is one that covers many problems. One of the supporting processes of Arabic language education is the curriculum. Without an education curriculum, it will harm the distribution of subjects, the realization of the goals of education, optimization of teaching methods, and learning media and other problems. Thus, affirming the existence of Arabic in the national education curriculum is very important and is required to continue to develop according to the challenges of the times.

Learning Arabic in Indonesia is the key to exploring old Indonesian literature. One of the arguments is that many Arabic/مصطلحات words and terminology are used and absorbed into Indonesian words. In addition, the effort to study Arabic in Indonesia is not only useful for understanding Islamic teachings and culture but is also useful for knowing the influence and role of Arabic in the development of a national culture where the majority of the population is Muslim. Furthermore, the development of learning Arabic in Indonesia, when examined, turns out to have three objectives of learning Arabic as a foreign language: (1) to recognize and understand the Qur'an and al-Hadith as well as the sharia (laws) contained in it. Inside it; (2) to establish contact with Arabs and establish good relations with native speakers; (3) for expertise or deepen it. $^{1}$

Next, the development of learning Arabic in the Dutch colonial era, before writing was taught in schools, the Arabic script was often used in correspondence. Even until the early days of independence, many people in the villages were still blind to Latin writing, but not blind to Arabic writing, at least to read the Qur'an and read letters in Arabic-Malay script. We can see this fact from several ancient heritages/relics, book essays, and tombstones that read 
Arabic Malay. ${ }^{2}$ Even in several neighboring countries, such as Malaysia and Brunei Darussalam, the use of Malay Arabic script still exists and is maintained.

The development of learning Arabic in Indonesia at the next stage consists of four (four) dimensions, starting from elementary to tertiary levels. The first dimension is the successive dimension with the abjadiyah method; the second dimension is the dimension of deepening the teachings of Islam for special purposes with the grammatical-translation method; the third dimension is the modern dimension with the direct method; while the fourth dimension is the uncertain dimension / الانتقائية but it is more likely that the learning process uses the grammatical-translation method and this is taught in formal madrasah with indicators of learning activities as follows: (1) Explanation of the rules of nahwu and sharaf by teaching staff and memorization of these rules by students; (2) Memorizing vocabularies then stringing them together according to grammatical rules; (3) Explanation of the contents of the reading by translating word by word then sentence by sentence; (4) Almost no practice using Arabic orally; (5) Have not used props or audio-visual aids. ${ }^{3}$

The Reason why enhancing learning Arabic is important because the curriculum of Arabic language education for students has not been properly and proportionally. The existing management is still in the form of a unified goal and approach without distinguishing between new and old students, between students who have competence and students who are weak or even very weak in Arabic language competence.

${ }^{1}$ Nazri Syakur, Revolusi Metodologi Pembelajaran Bahasa Arab: dari Pendekatan Komunikatif ke Komunikatif Kambium, (Yogyakarta: Pustaka Insan Madani, 2010), Page. 33.

${ }^{2}$ Ibid., Page. 37.

${ }^{3}$ Ahmad Fuad Effendy, MetodologiPengajaranBahasaArab, (Misykat: Malang, 2005), Page. $22-25$. 


\section{METHOD}

This study is a qualititative descriptive research. The research subjects is the curriculum books for Arabic. The data collection technique used documentation review. Data were analyzed by applying the four steps of Creswell's version collecting data, grouping, selecting, then interpreting the data and the data source was a documents review.

\section{RESULT AND DISCUSSION}

The urgency of enhancing learning Arabic inside national education curriculum in Indonesiacan be represented as below:

\section{A. General Education Curriculum}

The word curriculum etymologically happens in a race. This means that the route is commonly traversed and followed by competitors in a race. This becomes a standard rule for anyone who participates in the competition so usually adheres to the currere route.

In the world of education, experts interpret the term curriculum in different terms. The curriculum in the world of education as Ronald C. Doll said: "The school curriculum is a process content, both formal and informal, which is intended for students to acquire knowledge and understanding, develop skills and change the appreciation of attitudes and values with the help of schools". Meanwhile, Maurice Dulton said, "The curriculum is understood as experiences that learners get under the auspices of the school". ${ }^{4}$

In the Act Number 20 Year 2003 about National Education System. Education is defined as "The curriculum is a set of plans and arrangements regarding the objectives, content, and learning materials and methods used as

${ }^{4}$ Ali Mudlofir, AplikasiPengembanganKurikulum Tingkat Satuan Pendidikan Dan Bahan Ajar Dalam Pendidikan Agama Islam, (Jakarta: PT Raja GrafindoPersada, 2012),Page. 1-2. 
guidelines for implementing learning activities to achieve certain educational goals." ${ }^{15}$

From these definitions, the curriculum can be interpreted in three contexts, namely as some subjects that must be taken by students, as a learning experience, and as a learning program plan. The explanation of the three contexts is as follows:

1. The definition of curriculum as some subjects that must be taken by students is a curriculum concept that until now has colored many educational theories and practices. In this meaning, the curriculum is often associated with efforts to obtain a diploma, while the diploma it self is a description of the ability of a person who gets the certificate.

2. The definition of curriculum as a learning experience implies that the curriculum is all activities carried out by students both inside and outside of school, as long as these activities are under the responsibility and monitoring of the teacher (school).

3. The curriculum as a program/learning plan does not only contain program activities but also contains objectives that must be pursued along with evaluation tools to determine the success of achieving goals, besides that it also contains tools or media that are expected to be able to support the achievement of these goals. The curriculum as a plan is drawn up to smooth the teaching and learning process under the guidance and responsibility of the school or educational institution and its teaching staff.

According to Oliva, there are four sources of curriculum development principles, namely "empirical data (empirical data), experimental data (experimental data), stories/legends that live in a society (folklore of the curriculum), and common sense".

1. Curriculum development stages

There are four stages of curriculum development: ${ }^{6}$ 
a. Curriculum development at the macro level

At this level, curriculum development is discussed in the national scope, which includes tri-education centers, namely formal education, informal education, and non-formal education to achieve national education goals.

b. Curriculum development at the institutional level

Institutional/institutional level curriculum development includes three main activities, namely formulating school objectives or competency standards for graduates of each institution, determining program content and structure, and formulating overall curriculum implementation strategies.

c. Curriculum development at the subject level (field of study) Curriculum development at the field level of study is carried out in the form of compiling or developing a syllabus for the subject areas for each semester. The syllabus of a field of study contains competency standards, basic competencies, subject matter/learning, learning activities, indicators, assessment systems, time allocation, and learning resources/materials/tools. Syllabus development must be based on certain principles, including scientific, relevant, systematic, consistent, adequate, actual and contextual, flexible, and comprehensive.

d. Curriculum development at the level of learning in the classroom

To develop a curriculum at the learning level in the classroom, the teacher needs to prepare learning programs, such as module packages, study packages, and lesson plans (RPP).

In its implementation, the development of a curriculum has the following stages:

Stage 1: Feasibility study and needs analysis

At this stage, the curriculum developer conducts a program needs analysis and formulates various considerations, including what things should be developed.

${ }^{6}$ Willliam R. Gordon, Rosemarye T. Taylor and Peter F. Oliva, Developing The Curriculum, (USA: Pearson Education Inc, 2009), Page. 94-95. 
Stage 2: curriculum planning (initial draft)

At this stage, the curriculum developer compiles an initial curriculum-planning concept. Based on the ability formula to be developed in the first stage, curriculum objectives are then formulated that underlie the content formulation and expected curriculum structure. Furthermore, curriculum developers design learning strategies that include strategic approaches, methods, media, learning resources, and an assessment system based on predetermined success criteria at the initial stage of selecting methods, media, learning resources, and assessment techniques should refer to their respective principles. And adjusted to the ability of teachers in the field as well as the situation and conditions of educational institutions/schools

Stage 3: development of a curriculum operational plan

At this stage, curriculum development makes a curriculum operational plan, which includes the preparation of a syllabus, developing teaching materials, and determining learning resources, such as books, resources, modules, resource persons, and so on.

Stage 4: implementation of a limited trial of the curriculum in the field

The purpose of field trials is to determine the likelihood of implementation and success of the curriculum, what obstacles or problems occur, how the environment influences, what factors support it, and how to overcome obstacles or solve problems. Testing activities include preparation, implementation, evaluation, repair, and adjustment. Testing is usually carried out on a representative sample group.

Stage 5: curriculum implementation

At this stage, curriculum developers must carry out at least two main activities, namely (a) dissemination activities, namely implementing the curriculum in a broader scope, and (b) implementing a comprehensive curriculum for all types and levels of education. 
Stage 6: monitoring and evaluation of the curriculum

At this stage, the curriculum developer monitors and evaluates the curriculum, which includes the input stage according to the curriculum design and the results or impacts of curriculum implementation.

Stage 7: refinement and adjustment

At this stage, the curriculum developer must make improvements and adjustments if based on the results of monitoring and evaluation of the curriculum, things are deviating or not following the circumstances.

\section{B. Curriculum Development Basis ${ }^{7}$}

The basis for curriculum development is essentially the factors that must be considered when developing the curriculum for educational institutions, both in the school environment and outside the school. The main foundation of the curriculum is a philosophical basis (philosophical assumption), while the other foundations are the nature of science (epistemology), society and culture (society and culture), individuals/students (the individual), and (learning theories).

In line with the opinion of Robert S. Zais, Ralph W. Tyler (in Ornstein and Hunkins, 1988) put forward a view that is closely related to several aspects that underlie a curriculum.

1. Philosophical Basis

The philosophical foundation refers to the importance of philosophy in implementing, fostering, and developing, the curriculum in schools. In a general sense, philosophy is a radical, comprehensive, and profound way of thinking (Socrates) or a way of thinking that explores something as deeply as possible. Plato called philosophy the science of truth. Philosophy seeks to study various problems faced by humans, including problems of education. According to Mudyahardjo (1989), three systems of philosophical thought are very influential in educational thought in general and education in Indonesia 
in particular. The three philosophical systems, namely idealism, realism, and pragmatism.

Philosophy will determine the direction in which students are taken. Philosophy is a set of values that underlie and guide the achievement of educational goals. Therefore, the philosophy adopted by a particular nation or community group or that of an individual (in this case the teacher) will greatly influence the educational goals to be achieved. The philosophy adopted by a country will however color the goals of education in that country. Thus, the goals of education in one country will be different from other countries, according to the philosophy adopted by these countries. The goals of education are a comprehensive formula of what should be achieved. This objective contains statements regarding the abilities that students are expected to have in line with the value system and philosophy adopted.

In Indonesia during the Dutch colonial period, the curriculum was very much oriented towards the political interests of the Dutch kingdom at that time. Likewise, during the Japanese occupation, the existing curriculum was based on the philosophy of the Rising Sun country. During the New Order era, the work of national education, especially the educational curriculum, was adjusted to the demands and needs and the philosophy adopted by the Indonesian nation, namely Pancasila.

2. Psychological Basis ${ }^{8}$

Psychology is the study of human behavior, while the curriculum is an effort to determine educational programs to change human behavior. Therefore, curriculum development must be based on psychology as a reference in determining what and how behavior should be developed.

${ }^{7}$ Dakir, PerencanaandanPengembangan Kurikulum, (Jakarta: PT. Rineka Cipta, 2004), Page. 3.

8Ibid, Page. 4. 
a. Student Development and Curriculum

Since birth, children have shown uniqueness, such as their self-expression in the form of crying or certain movements. This illustrates that from birth the child has the potential to develop. Those who really believe in this condition often consider children as adults in small forms. J.J Rosseau, a French education expert, is among the fanatics of this view. He argued that everything is good from the hand of God, but human hands corrupt it. He believes that children should learn from direct experience. Another opinion says that the child is the result of environmental influences. This contradicts Rosseau's view.

Apart from these two views, some think that child development is a combination of nature and the environment. This flow recognizes human nature, which has potential from birth, but this potential will develop in a good and perfect way due to environmental influences. This flow is called the convergence flow with the character William Stern. Havighurst developed the final view with his theory of developmental tasks.

\section{b. Learning Psychology and Curriculum}

The psychology of learning is concerned with how individuals/students learn. Learning is defined as a process of behavior change that occurs through experience. All changes in behavior increase in the cognitive (knowledge), affective (attitude), and psychomotor (skills) aspects that occur due to the experience process.

Psychology or learning theory that develops can be grouped into three groups, namely mental discipline theory or faculty theory, behaviorism theory, and organismic theory or cognitive gestalt field.

The definition of teaching according to power theory is to train students in these resources. How to learn generally through memorization and practice. 
According to the Gestalt theory, the teacher's role is as a guide, not a conveyor of knowledge, and students act as processors of learning materials. This theory has a lot of influence on the practice of implementing curriculum in schools, the principles are:

1) Learning is based on the whole

2) Learning is the formation of personality

3) Learn thanks to understanding

4) Learning based on experience

5) Learning is a developmental process

6) Learning is a continuous process

7) Learning will be more successful if it is linked to students' interests, concerns, and needs.

c. Sociological Basis

The sociological foundation directs the study of the curriculum that is associated with society, culture, and the development of science.

1) Curriculum and Society

Society is an organized group of individuals who think of themselves as something different from other groups or societies. The curriculum as an educational program or design must be able to answer the challenges and demands of the community, not only in terms of program content but also in terms of approaches and implementation strategies. The application of theories, principles, and laws contained in all the sciences in the curriculum must be following the conditions of the local community so that the learning outcomes achieved by students will be more meaningful in their lives.

\section{2) Curriculum and Culture}

Culture is a pattern of behavior that is generally found in one society. All values that have been agreed upon by society can also be called culture. Culture is the result of human creativity, taste, and initiative, whichis 
manifested in three ways. First, ideas, concepts, ideas, values, norms, and regulations, second, activities, and thirdly objects made by humans.

Schools have a special task to provide experience to students with a tool called the curriculum. The curriculum is a reflection of the way people think, feel, aspire, or habits. Therefore, in developing a curriculum, teachers need to understand the culture.

d. Science and Technology

The influence of science and technology is quite extensive, covering all areas of life such as politics, economy, society, culture, religion, security, and education. With the rapid development of technology, the curriculum must be based on science and technology.

\section{Arabic Curriculum in Indonesia}

The development of learning Arabic in Indonesia at the next stage consists of four (four) dimensions, starting from elementary to tertiary levels. The first dimension is the successive dimension with the abjadiyah method; the second dimension is the dimension of deepening the teachings of Islam for special purposes with the grammatical-translation method; the third dimension is the modern dimension with the direct method; while the fourth dimension is the uncertain dimension / الانتقائية but it is more likely that the learning process uses the grammatical-translation method.And this is taught in formal madrasah with indicators of learning activities as follows: (1) Explanation of the rules of nahwu and sharaf by teaching staff and memorization of these rules by students; (2) Memorizing vocabularies (المفردات) then stringing them together according to grammatical rules; (3) Explanation of the contents of the reading by translating word by word then sentence by sentence; (4) Almost no practice using Arabic orally; (5) Have not used props or audio-visual aids. ${ }^{9}$

\section{$22-25$.}

${ }^{9}$ Ahmad Fuad Effendy, Metodologi Pengajaran Bahasa Arab, (Misykat: Malang, 2005), Page. 
The practice of learning Arabic based on the above dimensions is adjusted to the level of education. For beginners, the following dimensions are used with the aim that students can read the Qur'an. The second dimension is used for learning Arabic for those who already have basic skills, namely reading and writing Arabic. While the third and fourth dimensions are used for students, who already have grammatical skills / القواعد النحوية الصرفية to be able to read Arabic texts / the yellow book correctly and understand what is read. This Arabic learning model is known as Passive Arabic, which is of course not in line with the goals and methods formulated in the curriculum that takes place in formal schools today so that the achievement of the results is not optimal.

Efforts to reform the management of Arabic learning in Indonesia on a wider scale starting at the elementary level/ المرحلة الابتدائية to tertiary institutions/ المرحلة الجامعية (after reforms in the thirties), began in the early seventies with the main sponsor of the Ministry of Religion of the Republic of Indonesia. Starting with a national study by twelve IAINs through out Indonesia (1971), a workshop on the preparation of an Arabic language learning syllabus for elementary, intermediate, and advanced levels (1972), a workshop on the preparation of guidelines for the development of "Guidelines for Arabic Language Learning for Indonesian Speakers", and a series of training courses for Arabic teachers (1976). ${ }^{10}$

The Ministry of Religion's version of the Arabic language learning guidebook recommends the following: ${ }^{11}$

1. For the basic level, the aural-oral/سماعي and integrated system/ نظل approaches are used, with the mimicry-memorization/ترديدات للحفظ and patternpractice/ محفوظات methods.

10Ibid., Page. 26. 
2. For the intermediate level, the same as the basic level in addition to the poly systemic/نظرية الفروع approach.

3. For advanced level, direct method and grammatical-translation method are used.

Besides, the way to solve the problems of learning the Arabic inside national education curriculum in Indonesia can be represented as below: ${ }^{12}$

1. Planning Function (Planning)

Planning is an initial process when you want to do work both in the form of thoughts and frameworks so that the goals to be achieved get optimal results. Likewise, in learning Arabic, planning must be the first step that is considered by the teaching staff/managers as the supervisor of Arabic courses. Because planning is an important part of success, mistakes in determining Arabic learning planning will have fatal consequences for the continuity of Arabic learning.

2. Organizing Function

According to Terry, organizing is a basic activity of management, carried out to manage all the resources needed, including the human element, so that the work can be completed successfully. An organization in Arabic learning management will be able to run smoothly and following the objectives if it is consistent with the principles that design the organizational journey, which is of course by the concepts of Arabic learning and is carried out by professional teaching staff so that it can be applied consistently in the learning process. management of teaching and learning activities, starting from the distribution of learning units, the level of students' abilities, aids and media, and other related matters.

3. Implementation Function (Actuating) Implementation is the realization of the plans and organizations that have been made. In Arabic learning management, to carry out learning activities

${ }^{11}$ Ibid.

${ }^{12}$ George R Terry, Prinsip-PrinsipManajemen (Jakarta: BumiAksara, 2006), Page. 73. 
properly, one must at least pay attention to the following principles, namely: Objectives, syllabus models, learning activities, the role of teaching staff, the role of students, and the role of teaching materials.

4. Supervision Function (Controlling)

Supervision is the overall effort to observe the implementation of operational activities to ensure that these activities are by the predetermined plan. In Arabic language learning, supervision is defined as a continuous monitoring process to ensure the implementation of a consequent plan for revision, improvement, or development.

Afterwards, to enhance learning Arabic inside national education curriculum especially in Indonesia need studied in-depth (Holistically), starting from the objectives of learning Arabic, approaches, syllabus, methods, techniques to evaluation so that the map of solutions offered by the authors in this research study is clear. Arabic proverb says الحق بلا نظام يغلبه الباطل بنظام meaning: Truth without a good management system will be defeated by well-organized falsehood.

\section{Conclusion}

The National Education Curriculum or in Arabic is called المناهج التعليمية الوطنية, which is a curriculum developed in Indonesia based on the agreement of stakeholders and teaching staff. Of course, the curriculum abroad will be different if itis applied in this beloved country, namely Indonesia, because the curriculum can run effectively if it is by the geographical conditions, culture, level of knowledge, and the availability of technology in Indonesia. The curriculum has a very broad meaning and varies according to various sources. In general, the curriculum has the meaning of a planned system and an arrangement that regulates the content and teaching materials that guide teaching and learning activities. 
The authors recommended the existence of Arabic in the national education curriculum should be strengthened and developed, because Arabic is the language of Muslims, so it has a synergistic relationship with Indonesian society because Indonesia is the largest Muslim population country in the world whom practices the teachings of Islam. More than that, Arabic is currently the international language as in December 18, 1973, Arabic come into an official language of the United Nations (UN),

\section{References}

Al-Khûlî, Muhammad Ali, Asâlîb Tadrîs al-Lughah al-'Arabiyyah, al-Mamlakah al-'Arabiyyah as-Su'ûdiyyah, 1986, Ed. 2

Asrori, Imam, Sintaksis Bahasa Arab Frasa-Klausa-Kalimat, Misykat, 2004

Dakir, Perencanaan dan Pengembangan Kurikulum,PT. Rineka Cipta, 2004

Effendy, Ahmad Fuad,Metodologi Pengajaran Bahasa Arab, Misykat, 2005

Fatkurrohman, Sistem Pengajaran Bahasa Arab di Indonesia dan Problem Berbahasa Arab Secara Aktif, Jurnal Lisanan Arabiya, 2017

Law on the National Education System in Indonesia (No. 20/2003)

Mahmud, Ahmad Fuad, 'Ulyan, al-Mahârât al-Lughawiyyah; Mâhiyatuhâ Wa Tharâiq Tadrîsihâ, Dâr al-Muslim li an-Nasyr wa at-Tauzi', 1992

Mudlofir, Ali, Aplikasi Pengembangan Kurikulum Tingkat Satuan Pendidikan Dan Bahan Ajar Dalam Pendidikan Agama Islam, PT Raja Grafindo Persada, 2012

Syakur, Nazri,Revolusi Metodologi Pembelajaran Bahasa Arab: dari Pendekatan Komunikatif ke Komunikatif Kambium, Pustaka Insan Madani, 2010

Willliam R. Gordon, Rosemarye T. Taylor and Peter F. Oliva, Developing The Curriculum, Pearson Education Inc, 2009 